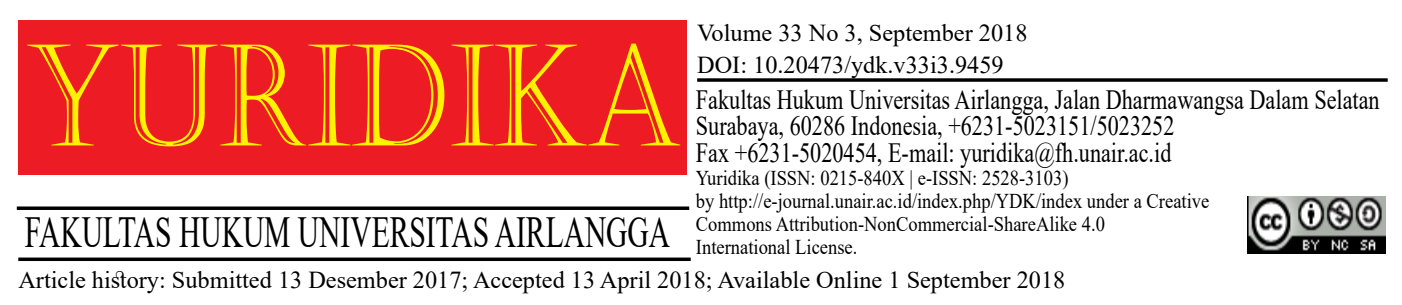

\title{
Distinction of Characteristics Sharia and Fiqh on Islamic Law
}

\author{
Prawitra Thalib \\ prawitra@fh.unair.ac.id \\ Universitas Airlangga
}

\begin{abstract}
Islamic law has a value of adaptability and flexibility, but also as a revelation that comes from God Almighty, Islamic law also are rigid, immortal and cannot be personalised way. The hallmark of the dynamics and flexibility combined with purity that can't be fickle that is what makes the uniqueness of the Islamic law as revelation that can answer the entire question of the contemporary that appeared at this time. To understand the Islamic law need to instil an understanding between sharia and fiqh. Of which in respect of Islamic law as revelation from God Almighty, then that's called Sharia, i.e. a set of international rules from God that its nature remains unchanged and immortal, but when looked at Islamic law is dynamic and flexible that it can adapt to the conditions of time and age then that is called fiqh. Which of course is part of the Islamic fiqh and must not be contrary to the Shariah, this article will lead to an understanding of the concept of Sharia and fiqh in General, to find the characteristics of the eternal, timeless until the day of resurrection, as well as dynamic and versatile development of the times.
\end{abstract}

Keywords: Islamic Law; Fiqh; Sharia.

\section{Introduction}

Sharia can be defined as a set of rules that was revealed God to man in order for guidelines in touch with God, each other, the environment and life everyday. Islamic law has characteristics that distinguish it from other legal systems in 
the world. ${ }^{1}$ About the science of fiqh is named after discussing sharia, fiqh term according to language or etymology means smart, intelligent, know and understand according to the asal-mulanya doctrine against the goal of a speaker and his talk. ${ }^{2}$ From one aspect, the science of fiqh, as with other Islamic sciences, can be said to have grown since the time of the Prophet himself. ${ }^{3}$ The relationship between sharia and fiqh essentially overlapped between one another, where sharia is the revelation that comes from God Almighty which are eternal, immortal and can not be changeable. While it is part of the Islamic fiqh derived from human reason, in an attempt to interpret the intent of God Almighty who stated in sharia, fiqh which has properties that contrary to sharia, that is dynamic, flexible and can be fickle follow the development of the times. ${ }^{4}$

Of course in sharia interpretation through the efforts of fiqh, the must follow the norms in force, that is not the case of wrong interpretation and definition of the error, so that it can be understood, though fiqh can vary so that fiqh must follow revelation, this can be in the following in regards to illustrate, suppose there is a carpenter who works with wood and meter, then ideally the wood at the cut follow the meter rather than vice versa, so it is with the sharia and fiqh, which in this case figh follow the sharia not the contrary. One of the most important characteristics of fiqh is the fleksibelity, which is the flexibility that the rules of fiqh is formulated based on two sources that are: ${ }^{5}$

\footnotetext{
1 Abd. Shomad, 'Karakteristik Ilmu Fiqh Muamalah' (2015) 20 Yuridika.[91]

2 Abd. Shomad, Hukum Islam: Penormaan Prinsip Syariah Dalam Hukum Indonesia (Kencana Prenada Media Group 2010).[27].

3 Misbahuddin, 'Fleksibilitas Penerapan Syariah Islam' (2010) 14 AL-FIKR <https://www. google.co.id/search?ei=KYifW6W5JtKm9QP9vJ-gDA\&q=fleksibel+penerapan+syariah+islam\& oq=fleksibel + penerapan + syariah + islam\&gs_l=psy-ab.3 ...4383.12455.0.13387.14.14.0.0.0.0.97.1 083.14.14.0...0...1c.1.64.psy-ab..0.10.777...33i22i29i30k1j33i160k1j33i21k1.0.vTmzzMeosfk\#>. [435].

4 Prawitra Thalib, Syariah: Konsep Dan Hermeneutika (Lutfansah Mediatama 2013).[19].

5 According Laldin "1. Ruling that are deduced from the decisive evidence from the Quran or Sunnah. This kind of rulings cannot be changed according to the change of time and place or cicumstances. There are only a few rulings of such nature and all the ruling related to ibadah falls under this category...2. ruling that are deduced by the scholars from their understanding and interpretations of the text of Quran or Sunnah and from other various sources of islamic law such as juristic preference, consideration of public interest, presumption of continuity, custom and others". Mohamad Akram Laldin, Introduction Shariah and Islamic Jurisprudence (2nd edn, CERT Publication 2006).[7].
} 
1. The rules are deducted from the evidence to determine that is derived from the Quran and Sunnah, this rule cannot be changed simply by virtue of the change of place, space and time, this rule only with regard to worship.

2. The rules deducted by Islamic scholars with the base on the understanding and interpretation of the contents of the content contained in the text of the Quran and Sunnah, in addition the consideration they eject also based on istihsan, masalih al mursalah, istihsab and urf. This effort is very dependent on the ability of Islamic law experts to maximize the ability of reasoning they have in solving the problems of fiqh that appear.

Regarding the differences between sharia and $f i q h^{6}$ Laldin explains that there are some differences from that two terms each of which shows the specifications of the two terms (the sharia and fiqh) which, among others, are: ${ }^{7}$

1. Sharia has a broader scope that encompassed the entire action and human performance, while the fiqh only leads to what is generally understood as a human action that is based on something that is legal and illegal.

2. Sharia contain that consists of the provisions found in the Quran and Sunnah which includes three main components namely, aqidah, fiqh, and akhlaq. Meanwhile fiqh is just is one component of sharia.

6 As for specifics regarding the development of fiqh is Campo also stated that "All of these traditions of fiqh continue to be followed today by Muslims, especially in matters of worship, personal status, and family law. The Hanafi School now prevails among Muslims in Turkey, iraq, Central Asia, Afghanistan, china, pakistan, and india. The Maliki School is followed mainly in North Africa, the sUdan, West and Central Africa, and Kuwait. The chief legal school in egypt, syria, east aFrica, South India, Sri Lanka, Southeast Asia, and the philippines is that of the Shafiis. The Hanbali School prevails in Saudi arabia and Qatar, and it has had a significant influence on many Muslims around the world. The Jaafari tradition of fiqh is followed by the Shia of iran, southern Iraq, southern lebanon, and parts of India and Pakistan. The different legal schools have come to agree that there are four fundamental sources, or "roots," of fiqh. Ranked in order of importance, they are the Quran, the sunna, consensus (ijmaa), and analogical reasoning (qiyas)'”. Juan E. Campo, Encyclopedia of Islam, Fact on File Inc (United States of America).[239].

7 Regarding this Laldin argues that "1. Shariah is the wider circle, it includes all human actions; but fiqh is confined to what are commonly understood as human acts as far as their legality and illegality are concerned, 2, shariah is the body of revealed injunctions found both in the Quran and Sunnah and it includes the following three main component...aqidah,...al ahkam al-akhlaqiyyah...al ahkam al-amaliyyah. It is obvious that fiqh is one component of the shariah, 3. Shariah is fix and unchangeable, whereas certain ruling of fiqh changes according to the changes of the circumstances under which it its applied, 4. The shariah is based on revelation in which the knowledge is only obtained from the Quran or Sunnah. In fiqh the power of reasoning is stressed and deductions based upon knowledge are continuously referred to with approval, 5. In fiqh an action is either legal or illegal but in the shariah there are various degrees of approval or disapproval". Mohamad Akram Laldin (n 5).Op.Cit.[8]. 
3. Sharia has been perfect and can't be changed, meanwhile changing fiqh follow the changes in time, space and place where the fiqh is applied.

4. Sharia is based on revelations that only derived from the Quran and Sunnah, fiqh, meanwhile, is a result of reasoning and deduction based on knowledge which is constantly evolving.

5. Sharia has some level of works ranging from being allowed to not allowed while it's fiqh only set about legal and illegal actions.

Yusuf Musa in his book entitled al Madkhal li Dirasah al Fiqh al Islamy also posited three Sharia and fiqh difference which among others is: ${ }^{8}$

1. Sharia has a wider coverage of fiqh, sharia because it covers the entire teaching of the religion i.e. aqidah, fiqh of worship and law while only includes the deed alone;

2. Its subject is the syariah of Allah SWT or al-Syar' $i$ while the subject of fiqh is human or al faqih, in this case the Sharia as a creation of God ALMIGHTY is both perfect and eternal truth, while fiqh can be changed according to the understanding of the faqih who caused by its historical and socio-cultural factors;

3. The difference in the origins of the use of the term, the term Sharia has been used from the early history of Islam while a new fiqh term used after the birth branches of religious sciences in Islam in the second century Hijri.

Against this Hanafi and Maliki are likely to insist on the distinction between Sharia and Fiqh. This is, as mentioned by An Naim explaining that "some scholars tend to emphasize a distinction between Shari'a and fiqh. Shari'a Law is the product of legislation (Shari'ah), of which God is the ultimate subject (shäri'a). Fiqh law consists of legal understanding, of which the human being is the subject ( fäqih)". ${ }^{9}$ According to the thinking of the Islamic sects as a law is the product of legilasi which in this case God (Allah) is the main subject which can not be replaced (syari '), whereas the fiqh is the law containing the legal sense where is people who

\footnotetext{
8 Renny Supriyatni, Pengantar Hukum Islam Dasar-Dasar Dan Aktualisasinya Dalam Hukum Positif (Widya Padjadjaran 2011).[12-14].

9 Peri Bearman,[et.,al.], The Law Applied Contextualizing The Islamic Shari'a (IB Tauris \& Co Ltd 2008).[329].
} 
become the subject (faqih), so in other words we can say that Sharia law is derived from the Lord God Almighty and the fiqh is the law that comes from human thought as sentient God Almighty. ${ }^{10}$

Commenting on the philosophy of Islamic law are certainly not regardless of the term of fiqh and Ushul fiqh, as for the basic science of fiqh as an understanding derived from Quran Surah (Q.S.) At-Tawba verse122 “liyatafaqqahu fiddin” which means "to deepen their knowledge of religion", this is the underlying formula of figh as a al-fahmu or al ilmu, specifically figh can be said as an understanding or the science of Sharia, that is used to understand the science of the Sharia as the rules of Allah for the people. ${ }^{11}$ However, it is necessary to understand that the public nature of the sharia, the absolute, eternal, Holy and sacred because it comes directly from Allah, so it could not and should not be modified by any man, while it's fiqh is a science that is special, the relatively and heavily influenced by conditions of place and time (qabil lin niqash, qabil lit taghyir). ${ }^{12}$

Ushul fiqh can be said also as an approach to the theory and methodology used in fiqh, to understand the rules set forth Allah i.e. sharia, in order to answer the questions that appear in the midst of mankind, so the Ushul fiqh is also often described as a process of intellectual activity that is thorough in its effort to find, obtain and understand the terms that are in the word of God Almighty, which was then in the transform into a system of rights and obligations. At the time of Muhammad Rasullullah words covering all aspects of fiqh in Islam i.e. theological, political, economics and law, because the Qur'an uses the term in a general sense in fiqh. Thus at the time of the beginning of the term Islamic fiqh as the term ilm ' is often used as the understanding is generally against the principles

\footnotetext{
${ }^{10}$ It is as mentioned by Leaman and Ali in his book stating that "Fiqh, derived from the root meaning to understand, is the term used for jurisprudence... Fiqh is the human attempt to interpret and implement the shari 'ah, God's revealed law. Unlike shari 'ah, which is understood to be universal, complete, and perfect, fiqh is a human discipline that involves disagreement and development over time". Oliver Leaman and Kecia Ali, Averros and His Philosophy (Revised Ed, Clarendon Press 1998).[38-39].

${ }^{11}$ Prawitra Thalib, 'Application of Qowaid Fiqhiyyah in Contemporary Islamic Law' (2016) 31 Yuridika.[109].

${ }_{12}$ Muhyar Fanani, Ilmu Ushul Fiqh Di Mata Filsafat Ilmu (Walisongo Press 2009).[13].
} 
of Islam and its laws. After the death of Muhammad Rasullullah, Muslims faced with new issues and are forced to use private considerations, the term used for the knowledge of fiqh that result from the use of intelligence and personal opinions while the word ilm' used for the knowledge gained from the series of narrators Sunnah or also called Perawi. ${ }^{13}$

Dynamics of Islam in answering all the demands of the era, at a time when it is experiencing a stagnant period failed to come to an end, Islam is seen not to be able to answer the new questions that have emerged along with the times, the which indirectly sparked the decline of Moslem today. Syibli Syumayyil carefully has showed that the decline of the Moslem today is caused due to the deviation of the teachings of Islam carried out by Moslem, not derived from the teachings of Islam itself. ${ }^{14}$

When discussing the Ushul fiqh and fiqh there are some important notes pertaining to Ushu fiqhl, first Ushul fiqh is not just limited to one study alone, namely the study of the law, but more than that its coverage extends to all subject matter for study in Islam, this is because Ushul fiqh is approaches, theories and methodologies used in understanding all of the teachings of Islam, this is also the underlying why fiqh also often referred to by the term al-science. Nowadays the science of fiqh are often are also attributed with hermeneutics, ${ }^{15}$ This is due to the same as the fiqh of hermeneutics is basically not directed to develop rules and procedures in order to understand the legal text, but it has a purpose that is hermeneutics philosophical trying to connect the thought and intent as well as the direction and the goal of a the text among readers in the past with the present reader (contemporary), it is also later

\footnotetext{
${ }^{13}$ Abd. Shomad (n 2).Loc.Cit.

${ }_{14}$ Murtadha Muthahhari, Hak-Hak Wanita Dalam Islam (Lentera Basritama 1995).[50].

15 The science of hermeneutics is originally derived from Christian tradition which uses a tripartie process or three process of hermeneutics in understanding the texts of Holy Scripture which then also has influence in the Islamic world, namely an effort in understanding the Quran in understanding the teachings of the law is more intended as instructions for the reviewer Al Quran, not to formulate rules or raw method in understanding the teaching of law in the Quran, this is because the hermeneutics have a bentu will the importance of the dialogue and dialectic (conversation) and understanding (understanding), it can be seen from the theory of Fazlur rahman is known by the term double movement. See, Muhyar Fanani (n 12).Op.Cit.[25].
} 
gave birth to what is called a hermeneutical process tripartite or three the process of hermeneutics which consists of understanding, interpretation and hermeneutics. ${ }^{16}$

As for the first process in comprehension (exegesis) research on the original meaning of the text based on the time and place of the origin, the second is an interpretation (interpretation), which seeks to track the contemporary meaning of the original meaning of the contained in the text, in other words this process attempted to translate the original meaning of the text based on the time and precise origin becoming a meaning that is adapted to the traditions that exist and flourish in the now, then the latter is the process of heremeneutic, i.e., an effort that seeks to formulate rules and methods used in the process of moving from where the original understanding of the heading to this now or contemporary meaning. Both i.e. the science of fiqh and Hermeneutics have proven to be equally used as an attempt to understand the texts of Scripture that was once a human grip, such validity is what causes both have an affinity between each other. ${ }^{17}$

About fiqh can also be categorized as a law derived from God (divine law), against this Halper also stated his opinion that: ${ }^{18}$

"Divine law, of course, is unchangeable. But, like any other law, it must be applied. Fiqh is the science of its application, by which answers are found for particular questions. In deriving these answers, the jurist must take into consideration whether the conditions of life the time and place within which Shari'a is being applied have changed since similar questions arose earlier. If conditions have changed, a figh ruling made on the basis of previouslyexisting conditions must of necessity be reconsidered to see whether the changes are relevant and material to the existing rule. Nor is legislation exempt from this process".

Knowledge of the Islamic community in the deployment called fiqh, fiqh is therefore play an important role in conducting the deliberations towards the sharia applied in muslim societies, not only that fiqh also determines the process of reasoning-Islamic legal reasoning that can be applied in a society as long as not contrary to the Qur'an as the main source of Islam.

\footnotetext{
16 ibid.[24].

17 ibid.[25].

${ }_{18}$ Peri Bearman (n 9).[et.,al.]Op.Cit.[52].
} 
Further development in the late 19th century the term 'ilm or knowledge used for Hadeeth and reports, while against the term fiqh is exclusively used for knowledge that is based on the use of intelligence and independent consideration. Later in the 19th century Hijri, a mujtahid started to build their thinking patterns so that there arose the sect in Islam, in this century of fiqh translated as the law quoted from the Quran and the Sunnah with the use of ijtihad (istinbat) perfect. Later in its development of new thoughts arise regarding the understanding of fiqh according to the Islamic scholars like Imam Al Ghozali, ${ }^{19}$ Ibnu Khaldun ${ }^{20}$ and Abdul Wahab Khalaf, ${ }^{21}$ so gradually the scope of the term fiqh narrows and eventually confined to legal matters, even more narrow again in the legal literature alone fiqh book. ${ }^{22}$

According to Al-Ghazali's major discussion of Ushul fiqh is not evidence in the specific sense but rather in the sense of general propositions, so that became the discussion in Ushul fiqh is not the text (a special proposition) but instead is a rule (evidence), therefore, in proclaiming the Ushul fiqh which note is merely legal syar'i postulates that kulli (General), so it can be said that the substance of Ushul fiqh is not a source of law but rules, However the source of law also remained covered in Ushul fiqh because discussion of the sources of law are part of the discussion about rules. Next Al-Ghazali also put a reason as a source of knowledge to develop norms, results of thought from his mind that according to Al-Ghazali has given it a thought that the content of the Ushul fiqh consist of the four parts of the law (ats-tsamrah), the sources of law (al-mutsmirah), the way of

\footnotetext{
${ }^{19}$ According to Imam Al Ghozali "fiqh that means understand and knowledge, but make a urf scholars have knowledge that describes the rules specific for syara ' abomination ' mukallaf, like, obligatory, illegal, mubah, makruh, Sunni, valid, fasid, batil, qadha, and kind “.

${ }^{20}$ To problems the Ibn Khaldun describes fiqh that "fiqh is a knowledge known him all of Allah in relation to all jobs mukallaf, well that obligatory, illegal and mubah should be taken (disitinbatkan) from Al The book and the Sunnah and from U.s. basis-basis which has been firmly upheld syara ', such as qiyas and for example. Once issued rules with ijtihad from dalil-dalilnya then issued it is named with fiqh".

${ }^{21}$ About fiqh as Khalaf Abd al Wahhab science States that "the science of fiqh is a knowledge of the laws of the Islamic jurisprudence concerning human action are taken from the evidence if possible in detail, or collection-a collection of Islamic Sharia law about human action taken based on detailed evidence if possible ".

${ }^{22}$ Abd. Shomad (n 2).Op.Cit.[28-29].
} 
the taking of the law (thuruq al-istitsmar), Mujtahid who likened as the inventor or the law (al-mustatsmir). ${ }^{23}$

To the difference of sharia and fiqh that technically could be used in indicating a number of principles or rules as a comparison between each other based on the speculative thinking supported by text-the text contained in the Qur'an and Sunnah or. In connection with this An Naim explain: ${ }^{24}$

"This distinction can be useful in a technical sense of indicating that some principles or rules, as compared to others, are more based on speculative thinking than textual support from the Qur'an and/or Sunna. But this does not mean that those which are taken to be Shari'a rather than fi qh are the direct product of revelation because the Qur'an and Sunna can neither be understood nor have any influence on human behavior except through the effort of fallible human beings. Although the law is of divine provenance, the actual constructionof the law is a human activity, and its results represent the law of God as humanly understood".

According to Al-Ghazali's important also for the underlined that the main patterns of Ushul fiqh is a composition between naql (revelation) and aql (reason), linkages between the two is not equal but storied relationship patterns, which in this case naql always have levels that is higher than the aql or intellect, so the sense must be subject to naql, this makes naql became ashl (principal) whereas common sense be far' (branch), in this case far ' should always be subject to the ashl, but this only applies to the question of the sources of law not to source knowledge in Ushul, it is also made in Ushul fiqh epistemology according to Ghazali is not only based on one aspect that is a source of law, but more than it should the overall observed, it does not make sense can serve as a source of law, as well as naql, however when there are vacancies naql, then the reason or aql can play a role in the race to fill the void or the law. ${ }^{25}$

So it needs to be affirmed that the central position as a source of law is naql nature bayani (evidence), but nevertheless the central position is just valid for the source of the law and not in the structure of the basic science of Ushul

\footnotetext{
${ }^{23}$ Muhyar Fanani (n 12).Op.Cit.[45].

${ }^{24}$ Peri Bearman (n 9).[et.,al.]Op.Cit.

${ }^{25}$ Muhyar Fanani (n 12).Op.Cit.[48-49].
} 
fiqh, according to Al-Ghazali is the bayan is evidence sam'i or revelation, for the proposition that the most powerful that arise not because of reasonable way but through a miracle, Furthermore he also argued at a consistency that is the source of law naql primary source, but the law is not a source of knowledge, this is because the object of the study of the science of Ushul fiqh is the application of norms and theories against detailed propositions or text for the sake of taking the laws contained in the text and this is one of the studies in the philosophy of Islamic law.

It does not mean that sharia is the product of divine revelation necessarily be derived from the Quran and the Sunnah, because though the sharia as a law Lord is sourced from actual construction of the Sharia also through human activity and produce a law Lord in a form that can be understood by any human being, because the law (syariah and fiqh) is not unloaded directly (in practice the Quran itself lowered gradually and incrementally) so except through understanding and thinking is people who make the laws can be applied in Islamic society. ${ }^{26}$

The notion of sharia in general there are two main opinions which are often used as reference the scholars of Islam, that is the opinion of Imam Abu Hanafiah, the founder of the Hanafi and Shafi imam Shafi'i founder, ${ }^{27}$ regarding the explanation

${ }^{26}$ About graduality principle in Islam is characterized from the process of the decline of the revelation in the Quran that occurred by gradual or up one by one, the part for the sake of parts, things that were also expressed by Groff in his writings that mention that "The Qur'an, or Koran as it is sometimes spelled, is the foundational text of Islam. Muslims believe it is the revealed word of God, disclosed gradually (over a period of twenty-two years) to the Prophet Muhammad via the angel Jibril... The Qur'an is believed to be stylistically perfect and inimitable - a fact that is often taken as evidence of its divine source - and has spawned countless commentaries and translations (or more accurately, 'interpretations')'.Peter S. Groff, Islamic Philosophy A-Z (Edinburgh University PressLtd 2007).[175-176].

${ }^{27}$ Regarding the development of the Hanafi this Campo outlines that "The Hanafi Legal School (madhhab) is one of the four Sunni traditions of Islamic law, and it is considered to be the most widespread. It was named after Abu Hanifa (d. 767), an Iraqi of Persian heritage, who was credited by later generations of legal scholars to be its founder. The school originated in the turbulent southern Iraqi city of Kufa, one of the earliest centers of Islamic learning outside the Arabian Peninsula". Then against the development of Shafi Campo also explained that "Shafii, Muhammad ibn Idris (767-820)leading legal theorist and eponymous founder of the Shafii Legal School Known as the "father of Muslim jurisprudence" (fiqh), al-Shafii was born in the area of Gaza in palestine to an arab family that claimed descent from the prophet Muhammad (ca. 570-632). He grew up in- 
of Sharia according to the two priests among others is: ${ }^{28}$

1. According to Imam Abu Hanafiah, Sharia is defined as all the teaching of revelation delivered by Muhammad PUBH good to his people, the revelation that is associated with lahiriyah or batiniyah. Against the opinion of the Hanafi scholars argue that Sharia is defined too widely because the teachings of Prophet Muhammad PBUH sourced from the revelation is the whole of the Islamic religion which includes beliefs, worship, Sharia, tasawwuf etc.

2. According to Imam Syafi'i Sharia is the revelation delivered by Rasullullah containing specific laws relating to the deeds of the flesh only, i.e., which govern human behavior:

a. Vertical, i.e. between man and his God called worship or hablumminallah.

b. Horizontally, i.e. the relationship between man and his fellow man and the surrounding natural environment or hablumminannas.

Islam as a law regulating relations between fellow human beings or Sharia in a sense can be divided into several narrow scope which among others is: ${ }^{29}$

1. Munakahat: that is part of Islamic law governing marriage, divorce, and all sorts of consequences from such a feat;

2. Wirasah/faraid: that is part of the Islamic law which regulates all issues related to the heir, heirs, and the heirs of heritage treasures;

3. Muamalat: that is part of Islamic law governing material problems, rights over objects, human relations Ordinance in sale and rent, borrow, borrow, Union etc.;

4. Jinayat/Ukubat: that is part of Islamic law governing the issue of the Act is liable to a punishment which consists of:

a. Jarimah Hudud that is a penalty based on the Quran and Sunnah;

b. JarimahTa'zir namely penalties based on consideration of the ruler or

mecca and is reported to have become skilled in archery and the composition of Arabic poetry.... Al-Shafii's major writings are the Risala (Treatise) and Kitab al-umm (Book of Guidance). In these and shorter works he laid the groundwork for what would become the prevailing system of Islamic jurisprudence. On the one hand, he rejected the Maliki position that law had to be based on the living example of the community in Medina. On the other, he strongly opposed the Hanafi school'sacceptance of reasoned opinion (ray) in legal rea soning because it was too arbitrary. Indeed, some rationalists wanted to bypass the hadith altogether. Instead, al-Shafii argued that all law should be derived from revelation, especially the Quran and the Sunna of Muhammad, as witnessed by the hadith”. Juan E. Campo (n 6).Op.Cit.[286-287] \& [616].

${ }^{28}$ Renny Supriyatni (n 8).Op.Cit.[17].

${ }_{29}$ M. Daud Ali, Hukum Islam Pengantar Ilmu Hukum Dan Tata Hukum Islam Di Indonesia (6th edn, Raja Grafindo Perkasa 1999).[50-51]. 
goverment;

5. Al Suthananiyah: that is part of Islamic law to discuss the question of Government, heads of State, taxes, as well as other issues related to ketata up his u.s.;

6. Siyar: that is part of Islamic law governing the Affairs of war, peace and the relationship between countries;

7. Mukhashamat: that is part of Islamic law governing the Court of Justice, as well as the judiciary.

The above description means that the sharia was not solely as a legal doctrine and judicial system which has the function of regulating society, or as a resolution of the dispute, but more than that the sharia is something deep in the soul of the muslim community, it is further explained by Hallaq in his notes that: ${ }^{30}$

“The Shari'a then was not only a judicial system and a legal doctrine whose function was to regulate social relations and resolve and mediate disputes, but also a pervasive and systemic practice that structurally and organically tied itself to the world around it in ways that were vertical and horizontal, structural and linear, economic and social, moral and ethical, intellectual and spritiual, epistemic and cultural and textual and poetic, among much else. The Shari'a was as much a way of living and of seeing the world as it was a body of belief and intellectual play".

The above opinion explains that sharia could be viewed as a system that practically, structural and organized has been tied to the world of around it i.e. vertically (hablumminallah), and horizontal (hablumminannas), linear and structural, economic and social, moral and ethical, intellectual and spiritual, epistemik and cultural, textual and poetic, more than on that sharia is as alive and looking at the world is simply as a container of trust and only as an intellectual game..$^{31} 32$

\footnotetext{
${ }^{30}$ Wael B. Hallaq, An Introduction To Islamic Law (Cambridge University Press 1997). [163-164].

31 Ian Richard Netton, Islam Christianity and Tradition A Comparative Exploration (Edinburgh Univeresity Press 2006).

${ }^{32}$ About this compare with the opinion in book Netton mentions that Islam is one of the real witnesses regarding the unification of ancient ideas of unity in diversity and variety in unity, it is as written in the his book that "Islamic structures bear a real witness to the ancient ideas of unity in diversity and diversity in unity. While the fundamental doctrines (aqa'id) remain constant, they are articulated within a framework of widely differing, and culturally conditioned, structures, hierarchies, patterns and intellectual milieux: there are, for example, in Sharia law, four Sunni madhahib, law schools; Islam itself divides into the two major branches of Sunnism and Shi' ism (with the latter dividing and subdividing into a plethora of smaller groups); a whole variety of schools of mediaeval theology developed like Mu'tazilism, Ash;arism and Maturidism".ibid.[92].
} 


\section{Conclusion}

Finally it can be said that the sharia and fiqh though has one link between each other, but the two are not the same, this is because sharia has a wider coverage of the fiqh, or in other words when discussing the regarding the issues of fiqh then it will definitely be discussing sharia, but also when discussing the sharia is not necessarily discussing fiqh, because coverage of sharia which includes aqidah, worship and law, much wider when compared with coverage of fiqh which only includes human action alone. Therefore, it is understood that in principle the nature immortal, eternal and not fickle embedded on sharia can be applied specifically in certain conditions and situations through deployment, fiqh and fiqh deployment on the other hand should be aligned and should not contradict sharia, because the truth is reasonable for the purposes of revelation is not the opposite of revelation that follow common sense.

\section{Bibliography}

Abd. Shomad, Hukum Islam: Penormaan Prinsip Syariah Dalam Hukum Indonesia (Kencana Prenada Media Group 2010).

__, 'Karakteristik Ilmu Fiqh Muamalah’ (2015) 20 Yuridika.

Ian Richard Netton, Islam Christianity and Tradition A Comparative Exploration (Edinburgh Univeresity Press 2006).

Juan E. Campo, Encyclopedia of Islam, Fact on File Inc (United States of America).

M. Daud Ali, Hukum Islam Pengantar Ilmu Hukum Dan Tata Hukum Islam Di Indonesia (6th edn, Raja Grafindo Perkasa 1999).

Misbahuddin, 'Fleksibilitas Penerapan Syariah Islam' (2010) 14 AL-FIKR.

Mohamad Akram Laldin, Introduction Shariah and Islamic Jurisprudence (2nd edn, CERT Publication 2006).

Muhyar Fanani, Ilmu Ushul Fiqh Di Mata Filsafat Ilmu (Walisongo Press 2009).

Murtadha Muthahhari, Hak-Hak Wanita Dalam Islam (Lentera Basritama 1995). 
Oliver Leaman and Kecia Ali, Averros and His Philosophy (Revised Ed, Clarendon Press 1998).

Peri Bearman, The Law Applied Contextualizing The Islamic Shari'a (IB Tauris \& Co Ltd 2008).

Peter S. Groff, Islamic Philosophy A-Z (Edinburgh University PressLtd 2007).

Prawitra Thalib, 'Application of Qowaid Fiqhiyyah in Contemporary Islamic Law' (2016) 31 Yuridika.

—

Renny Supriyatni, Pengantar Hukum Islam Dasar-Dasar Dan Aktualisasinya Dalam Hukum Positif (Widya Padjadjaran 2011).

Wael B. Hallaq, An Introduction To Islamic Law (Cambridge University Press 1997).

HOW TO CITE: Prawitra Thalib, 'Distinction of Characteristics Sharia and Fiqh on Islamic Law' (2018) 33 Yuridika. 